\title{
Comparative investigation of toxicity induced by UV-A and UV-C radiation using Allium test
}

\author{
Kültiğin Çavuşoğlu ${ }^{1}$ - Tuğçe Kalefetoğlu Macar ${ }^{2} \mathbb{D} \cdot$ Oksal Macar $^{2} \cdot$ Dilek Çavuşoğlu $^{3} \cdot$ Emine Yalçın $^{1}$
}

Received: 8 July 2021 / Accepted: 13 December 2021 / Published online: 15 January 2022

(c) The Author(s), under exclusive licence to Springer-Verlag GmbH Germany, part of Springer Nature 2021

\begin{abstract}
Organisms are increasingly exposed to ultraviolet (UV) rays of sunlight, due to the thinning of the ozone layer and its widespread use in sterilization processes, especially against the SARS-CoV-2 virus. The present study was conducted with the purpose of evaluating the damages of UV-A and UV-C radiations in Allium cepa L. roots. The effects of two different types of UV on some physiological, biochemical, cytogenotoxic, and anatomical parameters were investigated in a multifaceted study. Three groups were formed from Allium bulbs, one of which was the control group. One of the other groups was exposed to $254 \mathrm{~nm}$ (UV-C) and the other to $365 \mathrm{~nm}$ (UV-A) UV. Growth retardation effect of UV was investigated with respect to germination percentage, total weight gain, and root elongation, while cytogenotoxicity arisen from UV exposure was analyzed using mitotic index (MI) and chromosomal aberration (CA) and micronucleus (MN) frequency. Oxidative stress due to UV application was investigated based on the accumulation of malondialdehyde (MDA) and the total activities of superoxide dismutase (SOD) and catalase (CAT) enzymes. Also, anatomical changes induced by UV-A and UV-C were analyzed in root meristematic cells. UV treatments caused significant reductions in growth-related parameters. Both UV treatments caused a significant increase in MDA levels and induction of SOD and CAT enzymes in root meristematic cells. A decrease in MI and an increase in the frequency of $\mathrm{MN}$ and CAs were observed in root tip cells, indicating the cytogenotoxic effect of UV application. Anatomical damages such as epidermis cell damage, cortex cell damage, necrotic zones, giant cell nucleus, and indistinct transmission tissue occurred in cells exposed to UV. All of the physiological, biochemical, cytogenetic, and anatomical damages observed in this study were more severe in cells treated with UV-C compared to UV-A. This study suggested that UV exposure triggered growth inhibition, cytogenotoxicity, oxidative stress, and meristematic cell damages in A. cepa roots depending on the wavelength.
\end{abstract}

Keywords Allium cepa L. · Cytogenotoxicity $\cdot$ Meristematic cell damage $\cdot$ Oxidative damage $\cdot$ Radiation $\cdot$ UV

\section{Introduction}

Responsible Editor: Ludek Blaha

Tuğçe Kalefetoğlu Macar tugce.macar@giresun.edu.tr

1 Faculty of Science and Art, Department of Biology, Giresun University, 28049 Giresun, Turkey

2 Department of Food Technology, Şebinkarahisar School of Applied Sciences, Giresun University, 28400 Giresun, Turkey

3 Department of Plant and Animal Production, Atabey Vocational School, Isparta Applied Sciences University, 32200 Isparta, Turkey
Both the thinning of the ozone layer (Bernhard et al. 2020) and the increased use of UV in sterilization treatments cause people to be exposed to excessive amounts of UV radiation. Sterilization technology, which has an important place for the healthy sustainability of our daily life, has gained a much more vital importance with the recent SARS-CoV-2 pandemic. In addition to being used in the decontamination processes of foods, medicines, and hospital equipment, it is utilized to combat infections that may arise from water and sewerage. Chemicals that are often used for sterilization have disadvantages such as causing changes in the features of the targets, generating hazardous substances, and leaving residue (Mori et al. 2007; Lindblad et al. 2020). UV 
light, which has been widely used since the middle of the twentieth century, is an effective method in sterilization and disinfection. In addition to artificial sources such as UVemitting fluorescent lamps and mercury-vapor lamps, sunlight has distinct UV classes. UV-A, UV-B, and UV-C are types of radiations that exist in sunlight with wavelengths of $315-400 \mathrm{~nm}, 280-315 \mathrm{~nm}$, and 200-280 nm, respectively (Kaidzu et al. 2019).

UV radiation, which can be easily absorbed by intracellular molecules such as amino acids, nucleic acids, and membrane polypeptides, causes damages living organisms in case of high exposure (Hollósy 2002; De Jager et al. 2017; Roy 2017). It is defined as a "complete carcinogen" due to its non-selective deleterious properties and mutagenicity. In addition to its oxidative damage initiating effect, it is a definite tumor initiator and tumor promoter as a replication-, transcription-, and translation-preventive agent (D'Orazio et al. 2013; Roy 2017). Because 253.7-nm wavelength is the optimal UV absorption efficiency of DNA, UV-C (254 nm UV)-emitting UV lamps exhibit extraordinary germicidal capacity (Coohill and Sagripanti 2008). On the other hand, UV-A, including $365 \mathrm{~nm}$ wavelength, accounts for $6.3 \%$ of solar radiation reaching the Earth and is the least injurious component of UV radiation (Rahimzadeh et al. 2011). The efficacy of UV-A and UV-C irradiation against SARS-CoV-2 viral stock was tested and demonstrated by applying UV radiation directly to petri dishes containing the virus. UV-A irradiation has a much lower efficiency in virus inactivation (Heilingloh et al. 2020).

Excessive use of UV radiation for pathogen control causes a gradual increase in the incidence of anomalies on organisms after exposure. In this study, the effects of UV-C with the shortest wavelength in the UV spectrum and UV-A with the longest wavelength were investigated using the Allium test. Allium test is an effective, useful, and practical test system that is frequently used to evaluate the possible genotoxicity and cytotoxicity of environmental pollutants (Kalefetoğlu Macar et al. 2020; Macar 2020; Öztürk et al. 2020). An important reason for choosing the Allium test is that this organism has excellent correlations with mammalian test systems and is an important model for assessing toxicity in eukaryotic cells (Srivastava and Singh 2020).

This study aimed to reveal the effects of UV radiation types on Allium cepa and their mechanism of action from various parameters. Although there are similar studies on the effects of UV radiation in the literature, these studies generally focused on one type of radiation. The number of studies comparing the effects of UV radiation types is not very large. Considering that UV radiation is used unconsciously, especially for sterilization, these days when we have to live with the COVID-19 pandemic, this study is very important in terms of bringing the harmful effects of UV radiation back to the agenda. In this study, the effects of UV-A and UV-C radiations were investigated with multi-parameters using oxidant, antioxidant, physiological, cytological, genetic, and anatomical parameters, and the parameters were correlated with each other. Genotoxic potentials of UV-A and $\mathrm{UV}-\mathrm{C}$ radiations were analyzed using micronucleus (MN) and chromosomal aberration (CA) frequencies as well as mitotic index (MI), whereas germination rate, root elongation, and weight increase were selected as growth-related indicators. Additionally, oxidative stress-inductive effects of UV radiations were assessed via antioxidant enzyme activities)superoxide dismutase (SOD) (EC 1.15.1.1) and catalase (CAT) (EC 1.11.1.6)) and malondialdehyde (MDA) content. Investigation of the anatomical damages induced by UV also provides new data entry to the literature.

\section{Materials and methods}

\section{UV irradiation procedure}

A. cepa bulbs purchased from a grocery store in Giresun were cleansed from their old roots and outermost dry scales in the laboratory. Bulbs were separated into three groups (control, UV-C, and UV-A) of 50 individuals each after weighing the initial weights $(5.42-5.65 \mathrm{~g})$. Basal plates of bulbs in the control group were kept in contact with tap water during the experiment. In this study, UV-A and UV-B, which are the two extremes (the longest and the shortest two types) of UV rays, were preferred. UV-C and UV-A groups were irradiated with 254-nm UV and 365-nm UV radiations, respectively. A UVGL-58 Handheld UV Lamp was used for UV implementations. UV radiation treatments were applied to the relevant groups (UV-C and UV-A) from a distance of $20 \mathrm{~cm}$ from the top of beakers containing bulbs that contacted with tap water. In order to ensure that the UV reaches bulbs without being absorbed and for a sufficient transparency, all germination processes were carried out in quartz beakers. The experiment was carried out at room temperature and ended after $72 \mathrm{~h}$.

\section{Growth parameters}

Germination percentage, root length, and weight gain parameters were used to determine the effects of UV-A and UV-C on growth. Sprouting of adventitious roots from the basal plate was considered as "germination" to determine germination rates of the groups. Germination percentage was determined using following equation:

Germination percentage $(\%)=$ Number of germinated bulbs / Total number of bulbs $\times 100$.

The root lengths of bulbs were measured with a millimetric ruler, and the weight gains were determined by 
considering the differences between the bulb weights measured with a precision balance before and after the application period (Yalçın et al. 2019).

\section{Cytogenotoxicity assessment}

The terminal root tips $(1 \mathrm{~cm})$ were used to evaluate the cytogenotoxicity generated by UV treatments. Root tips were kept in 1:3 ratio of acetic-alcohol solution for 1 day following a 4-h-long saturated para-dichlorobenzene solution pretreatment (Hill and Myers 1945). Root pieces were hydrolyzed for $14 \mathrm{~min}$ in a $60{ }^{\circ} \mathrm{C}$ water bath in $1 \mathrm{~N} \mathrm{HCl}$. Following this process, the root pieces, which were thoroughly rinsed with tap water, were stained with Feulgen for $1.5 \mathrm{~h}$ at room temperature. The staining procedure was terminated by washing the roots under continuously running tap water for $10 \mathrm{~min}$. Root tips were crushed in 1 drop of acetic acid (Sharma and Gupta 1982). MI, CAs, and MN, used as indicators of cytogenotoxicity, were scored under a research microscope (Olympus CX41) at $500 \times$ magnification. A digital camera (Olympus C-5060) was utilized to photograph the slides. For each group, totally 1000 cells were screened to score CAs incidences including $\mathrm{MN}$, while totally 10,000 cells were taken into consideration to score MI. CAs, MN, and MI analyses were performed by scanning random areas from 10 different slides prepared separately for each group. Each slide was prepared using only one root tip. Each root tip was taken from 10 randomly selected bulbs from each group. MI was evaluated as a marker expressing the ratio of cells in mitosis to the total number of cells. Criteria mentioned by Fenech et al. (2003) were used to distinguish $\mathrm{MN}$ from parent cell nuclei. While MI analysis was used to reveal cytotoxicity caused by UV treatments, $\mathrm{MN}$ and $\mathrm{CA}$ analyses were performed to analyze genotoxicity.

\section{Antioxidant/oxidant balance}

The modified protocol of Heath and Packer (1968) was used to evaluate the accumulation of MDA, a product indicating fatty acid peroxidation in biological membranes. A total of $0.2 \mathrm{~g}$ frozen roots were prepared for homogenization in $4 \mathrm{ml}$ of $5 \%$ trichloroacetic acid solution by grinding until they became flour. The samples were then centrifuged (15 min: $12,000 \mathrm{rpm}: 25^{\circ} \mathrm{C}$ ). Two milliliters of supernatant was mixed with $2 \mathrm{ml}$ of $0.5 \%$ thiobarbituric acid prepared in $20 \%$ trichloroacetic acid solution. The freshly prepared mixture was heated in a water bath to allow the reaction to take place at $96{ }^{\circ} \mathrm{C}$ for $30 \mathrm{~min}$. The tubes were then moved to the ice bath for cooling. The samples were centrifuged (5 min: $10,000 \mathrm{rpm}: 25^{\circ} \mathrm{C}$ ) and the absorbance of the supernatant fraction at $600 \mathrm{~nm}$ and $532 \mathrm{~nm}$ was recorded through a spectrophotometer (Shimadzu UV-Vis spectrophotometer/
Mini-1240). The 600-nm absorbance was subtracted from 532-nm absorbance for omitting non-specific turbidity. MDA concentrations were calculated utilizing the extinction coefficient $\left(155 \mathrm{mM}^{-1} \mathrm{~cm}^{-1}\right)$.

SOD and CAT enzymes were extracted pursuant to the same assay mentioned by Zou et al. (2012). A total of $0.5 \mathrm{~g}$ segments from roots were weighed and chilled in liquid nitrogen. Samples were crushed with ice-cold pestle in extraction buffer (sodium phosphate buffer: $0.05 \mathrm{M}, \mathrm{pH}$ $7.5)$ and then centrifuged ( $\left.20 \mathrm{~min}: 14,000 \mathrm{rpm}:+4{ }^{\circ} \mathrm{C}\right)$. The supernatant collected from the homogenates was used to determine the activities of SOD and CAT enzymes.

The total SOD activity was assayed according to Beauchamp and Fridovich (1971). A total of $0.01 \mathrm{ml}$ of supernatant was added to $1.5 \mathrm{ml}$ of sodium phosphate buffer (0.05 M: pH 7.8) previously mixed with $0.28 \mathrm{ml}$ of distilled water, $0.3 \mathrm{ml}$ of riboflavin $(20 \mu \mathrm{M}), 0.3 \mathrm{ml}$ of methionine $(130 \mathrm{mM}), 0.3 \mathrm{ml}$ of nitro blue tetrazolium chloride $(750 \mu \mathrm{M}), 0.3 \mathrm{ml}$ of EDTA-Na $2(0.1 \mathrm{mM})$, and $0.01 \mathrm{ml}$ of polyvinylpyrrolidone (4\%). A total of $375 \mu \mathrm{mol} \mathrm{m} \mathrm{m}^{-2} \mathrm{~s}^{-1}$ fluorescent light was exposed to the assay mixtures containing SOD enzyme for $15 \mathrm{~min}$. The absorbance at $560 \mathrm{~nm}$ was spectrophotometrically measured (Shimadzu UV-Vis spectrophotometer/Mini-1240).

The total CAT activity was assayed according to Zhang et al. (2005). A total of $0.2 \mathrm{ml}$ of supernatant was added to sodium phosphate buffer (0.05 M: $\mathrm{pH} 7.8)$ previously mixed with hydrogen peroxide $(0.1 \mathrm{M})$ and distilled water. Decline of the absorbance was read spectrophotometrically (Shimadzu UV-Vis spectrophotometer/Mini-1240) at $240 \mathrm{~nm}$. All procedures for MDA, SOD, and CAT analysis were performed for three times.

\section{Determination of meristematic cell damages}

Meristematic cell damages caused by UV applications were investigated using the cross-sections of decapitated roots. Each root tip was taken from 10 randomly selected bulbs from each group. $1 \mathrm{ml}$ of methylene blue (1\%) was utilized to stain the cross-sections. Three slides for each bulb were analyzed for meristematic cell integrity under a research microscope (Olympus CX41) at $500 \times$ magnification. A digital camera (Olympus C-5060) was utilized to photograph the slides. The severity of the damages was classified as "no damage," "light damage," "moderate damage," and "intense damage."

\section{Statistics}

Data obtained from the analyses were subjected to ANOVA and Duncan's tests to assess the significance of differences 
$(p<0.05)$. Tables are presented to indicate the mean and standard deviation.

\section{Results and discussion}

\section{Growth parameters}

The first step in analyzing UV-induced growth regression was to check germination success (Table 1). UV treatments at $254 \mathrm{~nm}$ and $365 \mathrm{~nm}$ resulted in $40 \%$ and $31 \%$ reduction in the germination percentages of bulbs compared to control, respectively. Root elongation levels in UV-C and UV-A groups decreased by $87 \%$ and $53 \%$ compared to the control. UV-C and UV-A administrations inhibited the weight gains of the groups by $81 \%$ and $52 \%$, respectively. These results show that UV-C has a higher inhibitory effect on root growth compared to UV-A. Light is a crucial factor for a healthy growth of plants, and the harmful region of solar radiation may cause metabolic damages that can result in devastating effects on plant growth. In general, the effects of UV radiation differ between plant species (Teramura and Sullivan 1994). Decreased photosynthetic activity, changes in enzymatic reactions, abnormalities in chloroplasts, and peroxisome activities occur in UV-treated meristematic cells of plants (Santos et al. 2004, Qi et al., 2017, Çavuşoğlu et al. 2021). Depending on these changes, it is known that plant height, dry weight, leaf area decrease, and processes such as flowering regress (Tevini and Teramura 1989; Darras et al. 2019). The reductions observed in root length, weight gain, and germination rate in this study can be explained by these negative effects of UV radiation. It is reported in the literature that UV radiation retards physiological development in plant species (Sarghein et al. 2011). Hernandez-Aguilar et al. (2020) reported that UV-C radiation may cause tissue deteriorations affecting growth of Phaseolus vulgaris L. seedlings depending on time. In addition, Foroughbakhch Pournavab et al. (2019) demonstrated that different regions of UV radiation including UV-C caused remarkable damages in germination and growth in pine, soybeans, sunflower, and wheat. Even though responses of below-ground tissues of plants to UV remain unclear, Zhang et al. (2020) suggested that UV-B radiation reduced the length of meristem and elongation regions of Arabidopsis thaliana (L.) Heynh. roots due to a reduction in the number of meristem cells. The higher regression observed in growth parameters in the UVC-treated group in this study indicates that UV-C is more toxic. UV light with shorter wavelengths has higher energy and can penetrate deeper. Rahimzadeh et al. (2011) showed that the growth inhibition effect of UV-C in Satureja hortensis L. was much more severe than that of UV-A.

\section{Cytogenotoxicity assessment}

UV-radiation-induced MI, MN, and CA frequency in $A$. cepa roots are given Table 2. It was observed that MI was decreased in the UV-treated groups compared to the control. And also, MI of the group exposed to $254 \mathrm{~nm} \mathrm{UV}$ was significantly lower than that of both the control and $365 \mathrm{~nm}$ UV-treated group. MI has been used as a consistent marker of cell division rate because of the mito-depressive action of destructive factors such as toxic chemicals and UV radiation (Siddiqui and Alrumman 2020; Yalçın et al. 2020; Çavuşoğlu et al. 2021). UV causes disruption of microtubules, which allow chromosomes to be pulled to the poles in mitosis. Microtubule degradation is likely due to the direct effect of UV on the tubulin dimer. And also, DNA damages and chromosomal aberrations induced by UV cause cell

Table 2 Effects of UV radiation on CA frequency and MI

\begin{tabular}{llll}
\hline Damages & Control & UV-C & UV-A \\
\hline MI (\%) & 7.5 & 4.0 & 5.24 \\
DCN & $750.80 \pm 25.16 \mathrm{a}$ & $400.70 \pm 12.78 \mathrm{c}$ & $524.20 \pm 17.46 \mathrm{~b}$ \\
MN & $0.60 \pm 0.76 \mathrm{c}$ & $40.10 \pm 5.13 \mathrm{a}$ & $26.30 \pm 2.75 \mathrm{~b}$ \\
FRG & $0.00 \pm 0.00 \mathrm{c}$ & $57.30 \pm 5.72 \mathrm{a}$ & $45.40 \pm 4.81 \mathrm{~b}$ \\
VC & $0.00 \pm 0.00 \mathrm{c}$ & $44.80 \pm 4.86 \mathrm{a}$ & $31.90 \pm 3.66 \mathrm{~b}$ \\
SC & $0.16 \pm 0.32 \mathrm{c}$ & $41.50 \pm 4.55 \mathrm{a}$ & $30.20 \pm 3.52 \mathrm{~b}$ \\
B & $0.00 \pm 0.00 \mathrm{c}$ & $30.30 \pm 3.48 \mathrm{a}$ & $22.60 \pm 2.91 \mathrm{~b}$ \\
UDC & $0.00 \pm 0.00 \mathrm{c}$ & $24.70 \pm 2.94 \mathrm{a}$ & $17.50 \pm 2.34 \mathrm{~b}$ \\
MA & $0.00 \pm 0.00 \mathrm{c}$ & $15.20 \pm 1.52 \mathrm{a}$ & $9.60 \pm 1.16 \mathrm{~b}$ \\
VN & $0.00 \pm 0.00 \mathrm{c}$ & $10.60 \pm 1.18 \mathrm{a}$ & $5.80 \pm 0.90 \mathrm{~b}$ \\
\hline
\end{tabular}

The means shown with different letters $(a-c)$ in the same line were significant at $p<0.05$.

$D C N$ Dividing cell number, $M I$ mitotic index, $M N$ micronucleus, $F R G$ fragment, $V C$ vagrant chromosome, $S C$ sticky chromosome, $B$ bridge, $U D C$ unequal distribution of chromatin, $M A$ multipolar anaphase, $V N$ vacuolized nucleus.
Table 1 Effects of UV radiation on growth parameters

\begin{tabular}{llll}
\hline Groups & $\begin{array}{l}\text { Germination percentage }(\%) \\
(n=50)\end{array}$ & $\begin{array}{l}\text { Root length }(\mathrm{cm}) \\
(n=10)\end{array}$ & Weight gain $(\mathrm{g})(n=10)$ \\
\hline Control & 99 & $6.85 \pm 1.78 \mathrm{a}$ & $+3.75 \mathrm{a}(5.50 \pm 1.58-9.25 \pm 1.96)$ \\
UV-C & 60 & $0.92 \pm 0.53 \mathrm{c}$ & $+0.70 \mathrm{c}(5.65 \pm 1.60-6.35 \pm 1.77)$ \\
UV-A & 69 & $3.24 \pm 1.22 \mathrm{~b}$ & $+1.78 \mathrm{~b}(5.42 \pm 1.54-7.20 \pm 1.82)$ \\
\hline
\end{tabular}

*The means shown with different letters $(\mathrm{a}-\mathrm{c})$ in the same column were significant at $p<0.05$. 
cycle delays (Staxén et al. 1993). As a cumulative result of all these effects, MI decreases in cells exposed to UV. Supporting our findings, Verdes-Teodor et al. (2019) showed that UV-C radiation suppressed cell division in a timedependent manner in Cucurbita pepo L. root meristems. In another study investigating the repressive effect of UV-A, UV-B, and UV-C on mitotic activity in $P$. vulgaris roots, it was shown that all three UV types reduced the frequency of cell division in bean roots depending on the application time (Bara and Tiganasu 2005). Mitotic activity and elongation levels of the root cells may affect root growth rate of plants. According to our results, the decrease in both root growth and MI showed parallelism. De Oliveira et al. (2015) pointed to the MI, which is an indicator of the level of cell proliferation, as a cellular parameter that could be directly related to the root growth in plants.

Along with the change in MI, anomalies in chromosomal integrity were also observed in UV-treated groups, and different types of CAs were detected. Fragments, vagrants, bridges, sticky chromosomes, unequally distributed chromatins, anaphase multipolarities, and vacuolized nucleus as well as micronuclei formation were among the CAs arisen from UV exposure (Fig. 1). The increase in CAs frequency observed in this study can be explained by the genotoxic effects induced by UV application. UV light causes the formation of pyrimidine dimers in DNA, and these dimers induce chromosomal aberrations. UV light also decreases the nuclease activity, which plays a role in the DNA repair mechanism, and in this way, DNA repair is hindered. Unrepaired dimers cause gaps and single-stranded and doublestranded breaks after DNA replication (Cieminis et al. 1987). Fragment was the most abundant CA type in UV-C and UV-A. Clastogenic agents are known to induce fragment formation through chromosomal breakages and ultimately MN increase in cells (Hintzsche et al. 2017; Rubeena and Thoppil 2020). Vagrant and sticky chromosomes were among the most common CAs generated from UV administrations in Allium roots (Table 2). Vagrant formation suggests a spindle failure (Haq et al. 2017), while stickiness occurs due to chromosomal contraction, DNA condensation, and dissolution abnormalities in nucleoproteins (Yadav et al. 2019). Data of the present study showed that UV application caused anaphase bridge formation in the root cells of Allium. According to Fenech et al. (2020), clastogenic factors induce breaks in
Fig. 1 Chromosomal aberrations induced by UV radiation (a $\mathrm{MN}$ at interphase, $\mathbf{b}$ fragment at anaphase, $\mathbf{c}$ vagrant chromosome at anaphase, $\mathbf{d}$ vagrant chromosome (black arrow) and bridges (dotted arrows) at anaphase, e sticky chromosome, f unequal distribution of chromatin at telophase, $\mathrm{g}$ multipolar anaphase, $\mathbf{h} \mathbf{1}$ vacuolized nucleus)

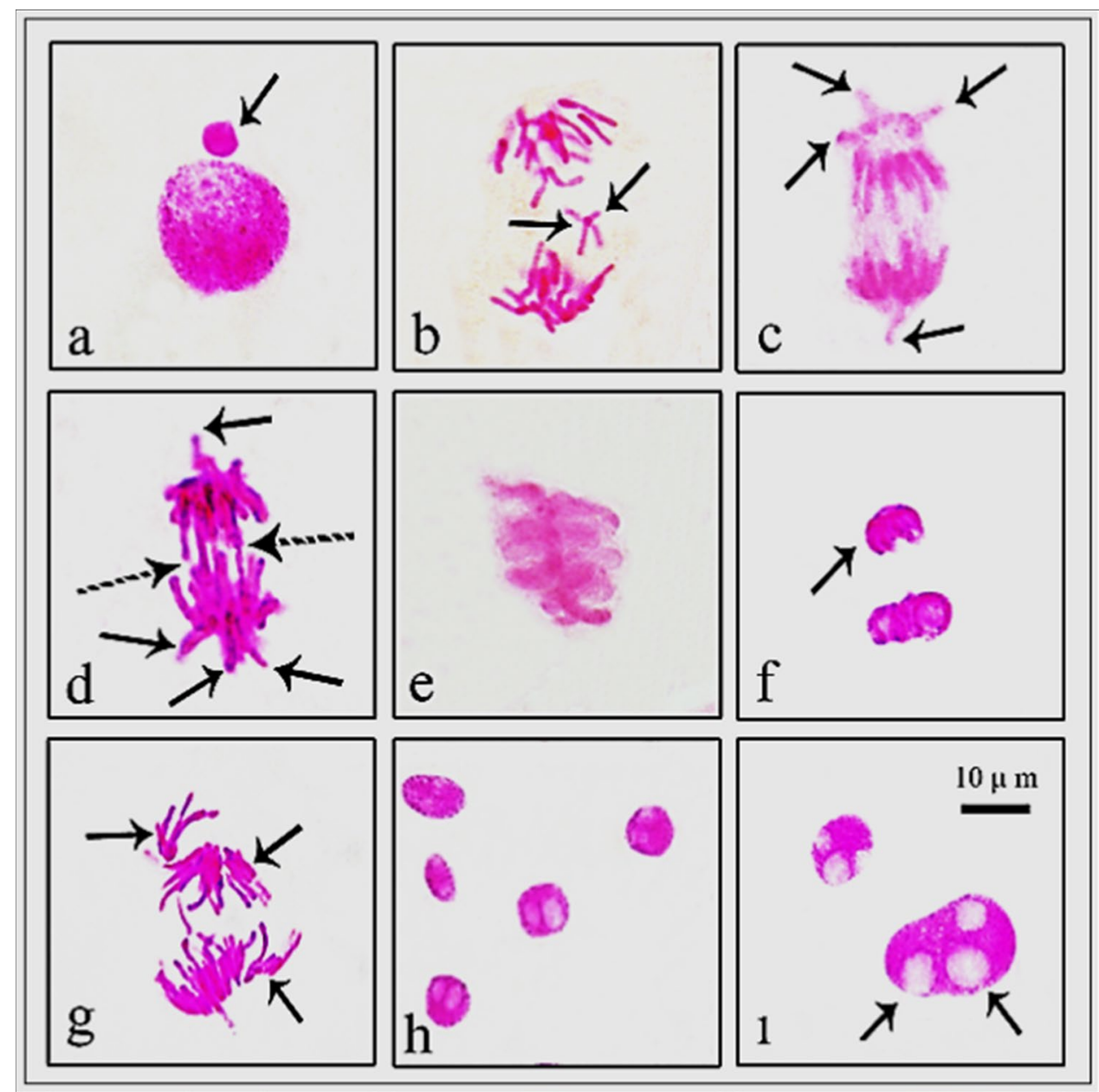


DNA chains, resulting in acentric chromosomes and various chromosomal rearrangements. These rearrangements may involve the generation of multi-centric chromosomes that give rise to the appearance of anaphase bridges. Another UV-provoked chromosomal anomaly was unequal distribution of chromatins. Dutta et al. (2018) stated that unequally distributed chromatins were consequences of a failure in disjunction of chromatins and were responsible for the rise in vagrant formation. In our study, anaphase multipolarity and vacuolized nucleus were the least frequent $C A$ s induced by UV treatments. Multipolar spindles and supernumerary (amplified) centromeres are the primary causes of multipolar anaphase (Vitre et al. 2020). On the other hand, vacuolized nucleus indicates a malfunction in the synthesis of DNA during mitosis (Sutan et al. 2014).

Plant nucleoli may also contain nucleolar spaces or vacuoles that are usually located within the nucleolus. These vacuoles are temporary storage sites of some biochemical structures such as ubiquitin-proteasome and snoRNA. These compounds, which are stored in the nuclear vacuoles, develop depending on the specific physiological requirements that arise especially against stress (Kalinina et al. 2018).

Similar to our study, previous studies showed that excessive UV undoubtedly induces genotoxic events in living organisms (Wang and Wang 1999; Atienzar et al. 2000; Molinier et al. 2005; Seven et al. 2015; Ibrahim et al. 2019).

Our study showed that UV exposure may be an apparent "MN-inducer." Although the increase in MN following $254 \mathrm{~nm}$ UV applications was extremely significant, the amount of MN caused by $365 \mathrm{~nm} \mathrm{UV}$ treatment was also remarkable. Indeed, MN frequencies of UV-C and UV-A were approximately 66.8 times and 43.8 times the control, respectively. UV irradiation may trigger genomic mutations as well as cellular mutations (Najafzadeh et al., 2011). MN is a routine test system utilized to detect the clastogenicity and aneugenicity of the pollutants (Hintzsche et al. 2017). While clastogenicity, known as chromosome breakage, can occur in cells at any stage of the cell cycle, aneugenicity (chromosome losses) can be observed only in cells undergoing mitosis (Udroiu et al. 2018). MN, which occurs as a result of cell division abnormalities, spindle damage, and chromosomal breaks, indicates the presence of clastogenic and aneugenic effects in the cell. In addition, acentric fragment formation and failures in spindle apparatus as well as chromosome losses at anaphase, are well-confirmed mechanisms associated with MN formation (Yasui et al. 2010; Russo and Degrassi 2018; Fenech et al. 2021). The high frequency of MN observed in UV-treated groups is evidence of the genotoxic effect on the cell. In particular, large-scale MN formation in UV-treated cells reinforces the particularly clastogenic effect of UV (Fig. 1a).
Another important result obtained in genotoxic analyses is that UV-C has a more toxic effect compared to UV-A. Although the penetration ability of UV-A is much stronger than UV-C, the reason why UV-C is more genotoxic is that the wavelength range of UV-C is closer to the absorption peak of DNA and RNA (Hsu et al. 2021). DNA photoproducts such as cyclobutane-type pyrimidine dimers and the pyrimidine $(6,4)$ pyrimidone dimer which tend to accumulate following UV-B and UV-C absorption of the cells may lead to mutations during replication (Hollósy 2002). While UV radiation is mostly absorbed by DNA in the UV-B and UV-C regions of the spectrum, absorption in the UV-A region is much weaker (Kiefer 2007). It is not surprising, then, that $254 \mathrm{~nm}$ UV had a higher capacity to reduce MI and increase $\mathrm{CA}$ and MN frequency compared to $365 \mathrm{~nm} \mathrm{UV}$. In fact, the main damage target of UV-C on cells is directly the DNA molecule, while the mechanism of damage caused by UV-A radiation is indirect damage of oxidative stress (Qiu et al. 2005).

\section{Antioxidant/oxidant balance}

Table 3 reflects the alterations in biochemical parameters related to antioxidant/oxidant balance deteriorated by UV treatments. MDA levels in the groups UV-C and UV-A raised to approximately 3.4 times and 2.4 times the control, respectively. A greater increase in MDA content in the $254 \mathrm{~nm}$ UV-treated group compared to the $365 \mathrm{~nm}$ UV-treated group indicated that UV-C caused a more serious oxidative burst in Allium root cells. As a cytotoxic material, MDA points out both the degree of lipid peroxidation in biological membranes caused by the over-production of reactive oxygen species (ROS) and the efficiency of the stress defense (Skórzyńska 2007; Luo et al. 2019). UV exposure causes ROS-mediated oxidative stress and lipid peroxidation in cells. MDA formed as a result of lipid peroxidation exhibits cytotoxic and mutagenic changes in cells. In this context, UV exposure directly causes lipid peroxidation and indirectly causes mutation. Similar to our results, Luo et al. (2019) reported a remarkable increase in MDA levels in UV-C radiationexposed grapes. In another study, UV-C pulses triggered

Table 3 Effect of UV radiation on biochemical parameters

\begin{tabular}{lccl}
\hline Groups & MDA $\left(\mu \mathrm{Mg}^{-1} \mathrm{FW}\right)$ & $\mathrm{SOD}\left(\mathrm{U} \mathrm{mg}^{-1} \mathrm{FW}\right)$ & $\begin{array}{l}\mathrm{CAT} \\
\left(\mathrm{OD}_{240 \mathrm{~nm}} \min \right. \\
\left.\mathrm{g}^{-1} \mathrm{FW}\right)\end{array}$ \\
\hline Control & $8.20 \pm 1.75 \mathrm{c}$ & $86.50 \pm 6.84 \mathrm{c}$ & $0.31 \pm 0.69 \mathrm{c}$ \\
UV-C & $28.20 \pm 3.16 \mathrm{a}$ & $227.80 \pm 14.10 \mathrm{a}$ & $0.90 \pm 1.12 \mathrm{a}$ \\
UV-A & $19.40 \pm 2.83 \mathrm{~b}$ & $166.90 \pm 09.32 \mathrm{~b}$ & $0.64 \pm 0.88 \mathrm{~b}$ \\
\hline
\end{tabular}

The means shown with different letters $(a-c)$ in the same column were significant at $p<0.05$. 
significant increases in MDA contents of tobacco callus in a time-dependent manner (Zacchini and de Agazio 2004). Although Tokarz et al. (2019) reported that UV-A application did not induce a remarkable alteration in MDA content in grass pea, our data on MDA content showed that UV-A exposure disturbed the membrane integrity in Allium roots.

UV-mediated oxidative stress may occur due to the direct relation of ionizing radiation with cellular macromolecules including DNA or may be induced by UVtriggered ROS accumulation (Rastogi et al. 2010; De Jager et al. 2017). Since UV exposure is inevitable for plants and UV light has a strong potential for ROS production, plants have evolved functional defense mechanisms including antioxidant enzymes against UV-mediated oxidative imbalance (Chen et al. 2019). SOD and CAT enzymes are among the key members of the enzymatic antioxidant defense system. SOD catalyzes the conversion of superoxide radicals to oxygen and hydrogen peroxide and is the first step in combating ROS. However, for accomplishing oxidative stress elimination, the increase in SOD activity should be supported by the enhanced activities of other enzymes such as CAT (Yalçın et al. 2019; Ibrahim et al. 2021). CAT enzyme takes part in the decomposition of hydrogen peroxide into water and oxygen (Foryer and Noctor 2000). The present study showed that UV exposure led to a sharp increase in the total activities of SOD and CAT enzymes. The total SOD activities in the groups UV-C and UV-A increased to nearly 2.6 times and 1.9 times the control, respectively. In addition, the total CAT activities of UV-C and UV-A were 2.9-fold and 2.1-fold of the control group. Our results demonstrating the rise in the enzyme activities confirmed Xie et al. (2009), who stated that SOD and CAT enzymes play important roles against UV. On the contrary to our data, Zacchini and de Agazio (2004) reported that CAT activity did not enhance in tobacco callus following UV-C irradiation. On the other hand, in another study, UV-B radiation caused an increase in CAT activity in barley (Mazza et al. 2001). Our data were consistent with Erkan et al. (2008), who demonstrated that UV-C illumination significantly stimulated SOD activity in strawberry fruits. Similarly, SOD and CAT activities in papaya fruits were enhanced following postharvest application of UV-C (Rivera-Pastrana et al. 2014). In our study, the increase in antioxidant enzyme activities associated with increased MDA level clearly revealed that UV exposure leads to the formation of ROS that also targets lipid peroxidation. The fact that the MDA level was higher in the UV-C-treated group compared to the UV-A-treated group indicates that ROS formation and oxidative damage are higher at $254 \mathrm{~nm}$ exposure. The antioxidant enzyme activities of the $254 \mathrm{~nm} \mathrm{U}$ - treated roots in our study were much higher than $365 \mathrm{~nm}$ UV radiation
Table 4 Meristematic cell damages induced by UV radiation

\begin{tabular}{llllll}
\hline Damages & ECD & N & GCN & CCD & ITT \\
\hline Control & - & - & - & - & - \\
UV-C & +++ & ++ & ++ & +++ & ++ \\
UV-A & ++ & + & + & ++ & + \\
\hline
\end{tabular}

$E C D$ epidermis cell damage, $N$ necrosis, $G C N$ giant cell nucleus, $C C D$ cortex cell damage, ITT indistinct transmission tissue, - no damage, + light damage, ++ moderate damage,+++ intense damage.

exposed group, proving that UV-C also triggered severe levels of ROS accumulation.

\section{Meristematic cell damages}

The effects of UV exposure on the meristematic tissue were monitored microscopically (Table 4; Fig. 2). Control treated with tap water throughout the experiment had no kinds of meristematic cell damages. On the other hand, UV-exposed groups exhibited various anomaly types in meristematic tissues including epidermis cell damage, necrosis, giant cell nucleus, cortex cell damage, and indistinct transmission tissue (Fig. 2). Epidermis and cortex cell damages were the most frequent damage types in both groups exposed to UV, but the degree of damage was more severe in UV-C group. Other disorder types observed in UV-C and UV-A were at "moderate" and "light" degrees, respectively. In our study, it was pretty clear that $254 \mathrm{~nm}$ UV had a much more destructive effect on meristematic tissue integrity than $365 \mathrm{~nm} \mathrm{UV}$. The deeper penetration of high-energy UV-C compared to UV-A causes intense anatomical changes.

UV radiation induces ultrastructural changes in meristematic cells, including rupture of cell membrane, damages in cortex, expansion of the nuclear membrane, swollen cisternae, and vesiculation (Sarghein et al. 2011). In this study, it was proved by the increase of MDA that UV application causes oxidative damage in meristematic cells. Oxidative damage causes abnormalities in many ultrastructural systems and macromolecules, including the cell membrane. These abnormalities cause disruption of cell dynamics and damage to many tissues in the root, especially the epidermis layer. Since the epidermis is a superficial tissue and transmits UV rays to the lower tissues, it was not surprising that there were severe deteriorations in cortex cells as well as in epidermis cells. Plants increase their phytochemical content to develop tolerance to UV toxicity. In particular, the production of flavonoids and many antioxidants from secondary metabolites increases, and these products are stored in the cell (Mohajer et al. 2015). This deposition also causes anatomical changes, 

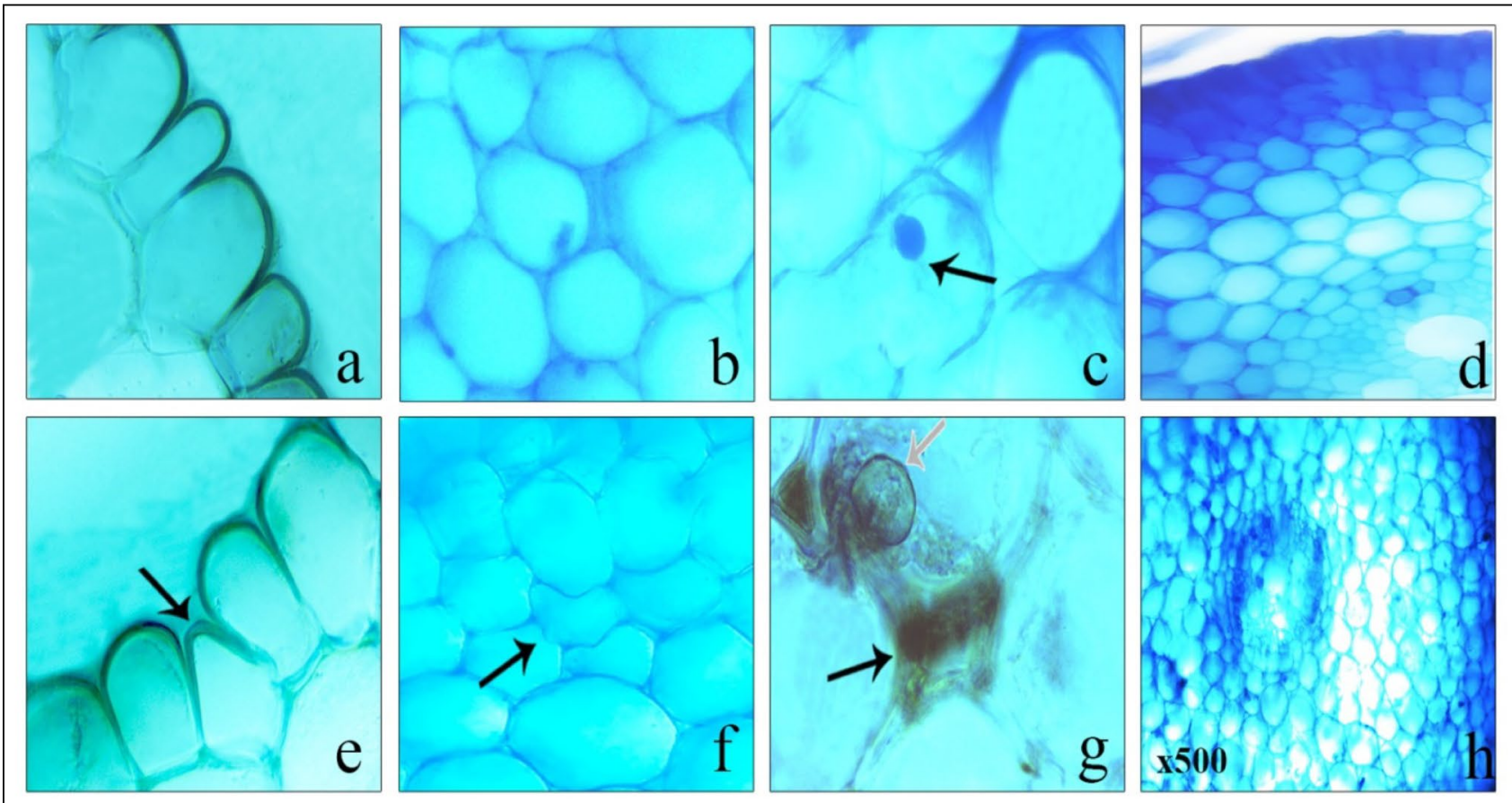

Fig. 2 Meristematic cell damages induced by UV (a normal appearance of epidermis cells, $\mathbf{b}$ normal appearance of cortex cells, $\mathbf{c}$ normal appearance of cell nucleus, $\mathbf{d}$ normal appearance of transmis-

especially in the conduction tissue. The malformations in the transmission bundles showed us how deep UV radiation could penetrate tissues. Previous studies have showed that UV-C modifies the root tissues in plants (Kareem et al. 2019). For instance, thickening of epidermal cells is one of the morpho-anatomical defense strategies against UV radiation in plants (DeLucia et al. 1992). Our results showing necrotic zones confirmed the suggestion of Zacchini and de Agazio (2004), who reported that excessive doses of UV radiation lead to an oxidative stress which in turn causes tissue necrosis and retarded plant growth.

\section{Conclusion}

This study demonstrated the harmful effects of UV-A and UV-C radiations commonly used in UV sterilizers on A. cepa, a recognized model organism. Both types of UV radiation induced growth suppression, cytogenotoxicity, cell membrane damage, and meristematic cell injuries. It was noticeable that antioxidant enzyme activities were stimulated in Allium roots to suppress oxidative stress caused by UV exposure. Here, we report that 254-nm UV had much more deleterious potential sion tissue, e epidermis cell damage, $\mathbf{f}$ cortex cell damage, $\mathbf{g}$ necrotic zones (black arrow) and giant cell nucleus (white arrow), $\mathbf{h}$ indistinct transmission tissue)

than 365-nm UV. Although UV radiation is one of the most advantageous methods for disinfecting or preventing pathogens including SARS-CoV-2, data of the present study showed that it may still pose a danger to non-target organisms.

Author contribution Dr. Kültiğin Çavuşoğlu, Dr. Tuğçe Kalefetoğlu Macar, Dr. Oksal Macar, Dr. Dilek Çavuşoğlu, and Dr. Emine Yalçın carried out the experimental stages, manuscript preparation, and statistical analysis.

Availability of data and materials All data and materials generated, utilized, or analyzed during this study are included in this published article.

\section{Declarations}

Ethics approval Not applicable.

Consent to participate Not applicable.

Consent for publication All the authors whose names appear on the submission approved the version to be published and agree to be accountable for all aspects of the work in ensuring that questions related to the accuracy or integrity of any part of the work are appropriately investigated and resolved.

Conflict of interest The authors declare no competing interests. 


\section{References}

Atienzar FA, Cordi B, Donkin ME, Evenden AJ, Jha AN, Depledge MH (2000) Comparison of ultraviolet-induced genotoxicity detected by random amplified polymorphic DNA with chlorophyll fluorescence and growth in a marine macroalgae. Palmaria Palmata Aqua Toxicol 50(1-2):1-12

Bara CI, Tiganasu OG (2005) The action of UV radiation on mitotic index and mitotic division phases at Phaseolus vulgaris L. J Exp Molec Biol 6:127-132

Beauchamp C, Fridovich I (1971) Superoxide dismutase: improved assays and an assay applicable to acrylamide gels. Anal Biochem 44:276-287

Bernhard GH, Neale RE, Barnes PW, Neale PJ, Zepp RG, Wilson SR, Andrady AL, Bais AF, McKenzie RL, Aucamp PJ, Young PJ, Liley JB, Lucas RM, Yazar S, Rhodes LE, Byrne SN, Hollestein LM, Olsen CM, Young AR, Robson TM, Bornman JF, Jansen MAK, Robinson SA, Ballaré CL, Williamson CE, Rose KC, Banaszak AT, Häder D-P, Hylander S, Wängberg S-Å, Austin AT, Hou W-C, Paul ND, Madronich S, Sulzberger B, Solomon KR, Li H, Schikowski T, Longstreth J, Pandey KK, Heikkilä AM, White CC (2020) Environmental effects of stratospheric ozone depletion, UV radiation and interactions with climate change: UNEP Environmental Effects Assessment Panel, update 2019. Photochem Photobiol Sci 19(5):542-584

Çavuşoğlu D, Macar TK, Macar O, Yalçın E, Çavuşoğlu K (2021) Extenuating role of lycopene against 254-nm UV-C radiationmediated damages in Allium cepa L. roots. Environ Sci Pollut Res, 1-10

Chen Z, Ma Y, Weng Y, Yang R, Gu Z, Wang P (2019) Effects of UV-B radiation on phenolic accumulation, antioxidant activity and physiological changes in wheat (Triticum aestivum L.) seedlings. Food Biosci 30:100409

Cieminis KGK, Rančelienė VM, Prijalgauskienė AJ, Tiunaitienė NV, Rudzianskaitė AM, Jancys ZJ (1987) Chromosome and DNA damage and their repair in higher plants irradiated with shortwave ultraviolet light. Mutat Res-Fund Mol M 181(1):9-16

Coohill TP, Sagripanti JL (2008) Overview of the inactivation by 254 $\mathrm{nm}$ ultraviolet radiation of bacteria with particular relevance to biodefense. Photochem Photobiol 84(5):1084-1090

Darras AI, Vlachodimitropoulou A, Dimitriadis C (2019) Regulation of corm sprouting, growth and flowering of pot Freesia hybrida L. plants by cold and UV-C irradiation forcing. Sci Hortic 252:110-112

De Jager TL, Cockrell AE, Du Plessis SS (2017) Ultraviolet light induced generation of reactive oxygen species. In: Ahmad S (ed) Ultraviolet light in human health, diseases and environment, advances in experimental medicine and biology 996. Springer, Cham, pp 15-23

De Oliveira C, Ramos SJ, Siqueira JO, Faquin V, de Castro EM, Amaral DC, Techio VH, Coelho LC, e Silva PHP, Schnug E, Guilherne LRG (2015) Bioaccumulation and effects of lanthanum on growth and mitotic index in soybean plants. Ecotoxicol Environ Saf 122:136-144

DeLucia EH, Day TA, Vogelman TC (1992) Ultraviolet-B and visible light penetration into needles of two species of subalpine conifers during foliar development. Plant Cell Environ 15(8):921-929

D'Orazio J, Jarrett S, Amaro-Ortiz A, Scott T (2013) UV radiation and the skin. Int J Mol Sci 14(6):12222-12248

Dutta J, Ahmad A, Singh J (2018) Study of industrial effluents induced genotoxicity on Allium cepa L. Caryologia 71(2):139-145

Erkan M, Wang SY, Wang CY (2008) Effect of UV treatment on antioxidant capacity, antioxidant enzyme activity and decay in strawberry fruit. Postharvest Biol Tech 48(2):163-171
Fenech M, Chang WP, Kirsch-Volders M, Holland N, Bonassi S, Zeiger E (2003) HUMN Project: detailed description of the scoring criteria for the cytokinesis-block micronucleus assay using isolated human lymphocyte cultures. Mutat Res 534:65-75

Fenech M, Knasmueller S, Bolognesi C, Holland N, Bonassi S, KirschVolders M (2020) Micronuclei as biomarkers of DNA damage, aneuploidy, inducers of chromosomal hypermutation and as sources of pro-inflammatory DNA in humans. Mutat Res Rev Mutat Res 786:108342

Fenech M, Knasmueller S, Knudsen LE, Kirsch-Volders M, Deo P, Franzke B, Stopper H, Andreassi MG, Bolognesi C, Dhillon VS, Laffon B, Wagner KH, Bonassi S (2021) "Micronuclei and disease" special issue: aims, scope, and synthesis of outcomes. Mutat Res Rev Mutat Res 788:108384

Foroughbakhch Pournavab R, Bacópulos Mejía E, Benavides Mendoza A, Salas Cruz LR, Ngangyo Heya M (2019) Ultraviolet radiation effect on seed germination and seedling growth of common species from Northeastern Mexico. Agronomy 9(6):269

Foryer C, Noctor G (2000) Oxygen processing in photosynthesis: regulation and signaling. New Phytol 146:359-388

Haq I, Kumar S, Raj A, Lohani M, Satyanarayana GNV (2017) Genotoxicity assessment of pulp and paper mill effluent before and after bacterial degradation using Allium cepa test. Chemosphere 169:642-650

Heath RL, Packer L (1968) Photoperoxidation in isolated chloroplasts: II. Role of electron transfer. Arch Biochem Biophys 125(3):850-857

Heilingloh CS, Aufderhorst UW, Schipper L, Dittmer U, Witzke O, Yang D, Zheng X, Sutter K, Trilling M, Alt M, Steinmann E, Krawczyk A (2020) Susceptibility of SARS-CoV-2 to UV irradiation. Am J Infect Control 48(10):1273-1275

Hernandez-Aguilar C, Dominguez-Pacheco A, Tenango MP, Valderrama-Bravo C, Hernández MS, Cruz-Orea A, Ordonez-Miranda J (2020) Characterization of bean seeds, germination, and phenolic compounds of seedlings by UV-C radiation. J Plant Growth Regul: $1-14$

Hill HD, Myers WM (1945) A schedule including cold treatment to facilitate somatic chromosome counts in certain forage grasses. Stain Technol 20:89-92

Hintzsche H, Hemmann U, Poth A, Utesch D, Lott J, Stopper H (2017) Fate of micronuclei and micronucleated cells. Mutat Res Rev Mutat Res 771:85-98

Hollósy F (2002) Effects of ultraviolet radiation on plant cells. Micron 33(2):179-197

Hsu TC, Teng YT, Yeh YW, Fan X, Chu KH, Lin SH, Yeh KK, Lee PT, Lin Y, Chen Z, Wu T, Kuo HC (2021) Perspectives on UVC LED: its progress and application. Photonics 8(6):1-19

Ibrahim ATA, AbouelFadl KY, Osman AG (2019) Ultraviolet A-induced hematotoxic and genotoxic potential in Nile tilapia Oreochromis niloticus. Photochem Photobiol Sci 18(6):1495-1502

Ibrahim MFM, Ibrahim HA, Abd El-Gawad HG (2021) Folic acid as a protective agent in snap bean plants under water deficit conditions. J Hortic Sci Biotech 96(1):94-109

Kaidzu S, Sugihara K, Sasaki M, Nishiaki A, Igarashi T, Tanito M (2019) Evaluation of acute corneal damage induced by $222-\mathrm{nm}$ and 254-nm ultraviolet light in Sprague-Dawley rats. Free Radic Res 53(6):611-617

Kalefetoğlu Macar T, Macar O, Yalçın E, Çavuşoğlu K (2020) Resveratrol ameliorates the physiological, biochemical, cytogenetic, and anatomical toxicities induced by copper (II) chloride exposure in Allium cepa L. Environ Sci Pollut Res 27(1):657-667

Kalinina NO, Makarova S, Makhotenko A, Love AJ, Taliansky M (2018) The multiple functions of the nucleolus in plant development, disease and stress responses. Front Plant Sci 9:132

Kareem KA, Olobatoke TJ, Rahaman AA, Mustapha OT (2019) Mutagenic effects of ultraviolet (UV-C) irradiation on the 
anatomy of three species of Capsicum. Bangladesh J Sci Ind Res 54(2):111-116

Kiefer J (2007) Effects of ultraviolet radiation on DNA. In: Obe G, Vijayalaxmi (eds) Chromosomal alterations. Springer, Berlin, Heidelberg, pp 39-53

Lindblad M, Tano E, Lindahl C, Huss F (2020) Ultraviolet-C decontamination of a hospital room: amount of UV light needed. Burns 46(4):842-849

Luo YY, Li RX, Jiang QS, Bai R, Duan D (2019) Changes in the chlorophyll content of grape leaves could provide a physiological index for responses and adaptation to UV-C radiation. Nord J Bot 37(4):1-11

Macar O (2020) Multiple toxic effects of tetraconazole in Allium сера $\mathrm{L}$. meristematic cells. Environ Sci Pollut Res 1-8

Mazza CA, Battista D, Zima AM, Szwarcberg-Bracchitta M, Giordano CV, Acevedo A, Scopel AL, Ballare CL (2001) The effect of solar ultraviolet-B radiation on the growth and yield of barley are accompanied by increased DNA damage and antioxidant responses. Plant Cell Environ 22:61-70

Mohajer S, Taha RM, Mohajer M, Javan IY (2015) UV-B irradiation effects on biological activities and cytological behavior of Sainfoin (Onobrychis viciifolia Scop.) grown in vivo and in vitro. Pak J Bot 47(5): 1817-1824

Molinier J, Oakeley EJ, Niederhauser O, Kovalchuk I, Hohn B (2005) Dynamic response of plant genome to ultraviolet radiation and other genotoxic stresses. Mutat Res-Fund Mol Mech Mut 571(1-2):235-247

Mori M, Hamamoto A, Takahashi A, Nakano M, Wakikawa N, Tachibana S, Ikehara T, Nakaya Y, Akutagawa M, Kinouchi Y (2007) Development of a new water sterilization device with a 365 nm UV-LED. Med Biol Eng Comput 45(12):1237-1241

Najafzadeh M, Baumgartner A, Gopalan R, Davies JB, Wright A, Reynolds PD, Anderson D (2011) In vitro sensitivities to UVA of lymphocytes from patients with colon and melanoma cancers and precancerous states in the micronucleus and the Comet assays. Mutagenesis 27(3):351-357

Öztürk G, Çavuşoğlu K, Yalçın E (2020) Dose-response analysis of potassium bromate-induced toxicity in Allium cepa L. meristematic cells. Environ Sci Pollut Res 27(34):43312-43321

Qi H, Duan L, Wang S, Wang Y, Zhang Q, Feng G, Du H, Liang Q, Lin Y (2017) Effect of enhanced UV-B radiation on cotton growth and photosynthesis. Chin J Eco-Agric 25(5):708-719

Qiu X, Sundin GW, Wu L, Zhou J, Tiedje JM (2005) Comparative analysis of differentially expressed genes in Shewanella oneidensis MR-1 following exposure to UVC, UVB, and UVA radiation. J Bacteriol 187(10):3556-3564

Rahimzadeh P, Hosseini S, Dilmaghani K (2011) Effects of UV-A and UV-C radiation on some morphological and physiological parameters in Savory (Satureja hortensis L.). Ann Biol Res 2(5):164-171

Rastogi RP, Kumar A, Tyagi MB, Sinha RP (2010) Molecular mechanisms of ultraviolet radiation-induced DNA damage and repair. J Nucleic Acids 592980

Rivera-Pastrana DM, Gardea AA, Yahia EM, Martínez-Téllez MA, González-Aguilar GA (2014) Effect of UV-C irradiation and low temperature storage on bioactive compounds, antioxidant enzymes and radical scavenging activity of papaya fruit. J Food Sci Technol 51(12):3821-3829

Roy S (2017) Impact of UV radiation on genome stability and human health. In: Ahmad S (ed) Ultraviolet light in human health, diseases and environment, advances in experimental medicine and biology 996. Springer, Cham, pp 207-219

Rubeena M, Thoppil JE (2020) Genotoxicity evaluation of Cissus latifolia Lam. and its genoprotective effect on oxidative damage induced by hydrogen peroxide. Asian J Pharm Clin Res 13(7):185-191
Russo A, Degrassi F (2018) Molecular cytogenetics of the micronucleus: Still surprising. Mutat Res Genet Toxicol Environ Mutagen 836:36-40

Santos I, Fidalgo F, Almeida JM, Salema R (2004) Biochemical and ultrastructural changes in leaves of potato plants grown under supplementary UV-B radiation. Plant Sci 167(4):925-935

Sarghein SH, Carapetian J, Khara J (2011) The effects of UV radiation on some structural and ultrastructural parameters in pepper (Capsicum longum A. DC.). Turk J Biol 35(1):69-77

Seven B, Çavuşoğlu K, Yalçın E, Çavuşoğlu K (2015) Allium cepa L. (Amarylidaceae) kök ucu hücreleri üzerine ultraviyole radyasyonun fizyolojik ve genotoksik etkilerinin araştirilmasi. CFD 36(5):24-31

Sharma PC, Gupta PK (1982) Karyotypes in some pulse crops. Nucleus 25:181-185

Siddiqui S, Alrumman S (2020) Cytological changes induced by clethodim in Pisum sativum plant. Bangladesh J Bot 49(2):367-374

Skórzyńska PE (2007) Lipid peroxidation in plant cells, its physiological role and changes under heavy metal stress. Acta Soc Bot Pol 1:49-54

Srivastava AK, Singh D (2020) Assessment of malathion toxicity on cytophysiological activity, DNA damage and antioxidant enzymes in root of Allium cepa model. Sci Rep 10(1):1-10

Staxén I, Bergounioux C, Bornman JF (1993) Effect of ultraviolet radiation on cell division and microtubule organization in Petunia hybrida protoplasts. Protoplasma 173(1):70-76

Sutan NA, Popescu A, Mihaescu C, Soare LC, Marinescu MV (2014) Evaluation of cytotoxic and genotoxic potential of the fungicide ridomil in Allium cepa L. An Stiint Univ Al I Cuza Iasi 60(1):5-12

Teramura AH, Sullivan JH (1994) Effects of UV-B radiation on photosynthesis and growth of terrestrial plants. Photosynth Res 39(3):463-473

Tevini M, Teramura AH (1989) UV-B effects on terrestrial plants. Photochem Photobiol 50(4):479-487

Tokarz K, Piwowarczyk B, Wysocka A, Wójtowicz T, Makowski W, Golemiec E (2019) Response of grass pea (Lathyrus sativus L.) photosynthetic apparatus to short-term intensive UV-A: red radiation. Acta Physiol Plant 41(10): 1-7

Udroiu I, Marinacci J, Bedini A, Giliberti C, Palomba R, Sgura A (2018) Genomic damage induced by $1-\mathrm{MHz}$ ultrasound in vitro. Environ Mol Mutagen 59(1):60-68

Verdes-Teodor A, Vochita G, Creanga D (2019) On some genotoxic effects of UV-C radiation in root meristemes in Cucurbita pepo L. Rom Rep Phys 71:707

Vitre B, Taulet N, Guesdon A, Douanier A, Dosdane A, Cisneros M, Maurin J, Hettinger S, Anguille C, Taschner M, Lorentzen E, Delaval B (2020) IFT proteins interact with HSET to promote supernumerary centrosome clustering in mitosis. EMBO Rep 21(6): 49234

Wang S, Wang X (1999) The Tradescantia-micronucleus test on the genotoxicity of UV-B radiation. Mut Res-Fund Mol Mech Mut 426(2):151-153

Xie Z, Wang Y, Liu Y, Liu Y (2009) Ultraviolet-B exposure induces photo-oxidative damage and subsequent repair strategies in a desert cyanobacterium Microcoleus vaginatus Gom. Eur J Soil Biol 45(4):377-382

Yadav A, Raj A, Purchase D, Ferreira LFR, Saratale GD, Bharagava RN (2019) Phytotoxicity, cytotoxicity and genotoxicity evaluation of organic and inorganic pollutants rich tannery wastewater from a Common Effluent Treatment Plant (CETP) in Unnao district, India using Vigna radiata and Allium cepa. Chemosphere 224:324-332

Yalçın E, Uzun A, Çavuşoğlu K (2019) In vivo epiclorohidrine toxicity: cytogenetic, biochemical, physiological, and anatomical evidences. Environ Sci Pollut Res 26(22):22400-22406 
Yalçın E, Çavuşoğlu K, Acar A, Yapar K (2020) In vivo protective effects of Ginkgo biloba L. leaf extract against hydrogen peroxide toxicity: cytogenetic and biochemical evaluation. Environ Sci Pollut Res 27(3):3156-3164

Yasui M, Koyama N, Koizumi T, Senda-Murata K, Takashima Y, Hayashi M, Sugimoto K, Honma M (2010) Live cell imaging of micronucleus formation and development. Mutat Res-Fund Mol M 692(1-2):12-18

Zacchini M, de Agazio M (2004) Spread of oxidative damage and antioxidative response through cell layers of tobacco callus after UV-C treatment. Plant Physiol Biochem 42(5):445-450

Zhang H, Jiang Y, He Z, Ma M (2005) Cadmium accumulation and oxidative burst in garlic (Allium sativum). J Plant Physiol 162(9):977-984
Zhang P, Wang R, Wang Y, Xu J (2020) Ultraviolet-B radiation induces cell death in root tips and reprograms metabolism in Arabidopsis. Biol Plant 64:764-772

Zou J, Yue J, Jiang W, Liu D (2012) Effects of cadmium stress on root tip cells and some physiological indexes in Allium cepa var. agrogarum L. Acta Biol Cracov Bot 54:129-141

Publisher's note Springer Nature remains neutral with regard to jurisdictional claims in published maps and institutional affiliations. 